\title{
Using Digital Media in Civics Education Learning Subject to Develop Santri's Digital Literacy at the Age of Technology Disruption
}

\author{
Andika Limas Putra, Muchtarom, M. Triana Rejekiningsih
}

\begin{abstract}
This research aims to describe the development strategies of students' (Santri) digital literacy skills in modern Islamic boarding schools through Civics Education Learning Community Education. Civics Education is a school subject that has a strategic role in shaping the young citizens' digital competence. The development of digital literacy in Santri discussed in this research is divided into two aspects, among others are the technology literacy and information literacy. This research is designed with qualitative research methods. The data collection technique applied purposive sampling. The research subjects were both students and teachers of Civics Education subject in Modern Islamic Boarding School. The data collection technique carried out by applying interview techniques, observation and document analysis. The data analysis techniques cover the data reduction, data presentation, conclusion, and verification. Before conducting this research regarding the Santri's digital literacy development strategies, researchers first explored santri's digital literacy skills. The results of this research indicated that, there is a digital divide phenomenon among the santri(s)' attitudes and pesantren with regard to current policies using technological advancements. Then, the development of digital literacy skills is identifiable from the learning and evaluation process. The development of digital literacy skills through the learning process of Civics Education carried out through using digital media. It effectively helps santri develop their skills using technology, in addition to developing santri(s') in processing information through digital media. The Santri's learning skills in using digital media using the Civics Education reflects common effective strategies in developing their skills in realizing information, searching, and using information
\end{abstract}

Index Terms: Digital Literacy Skills; Santri; Civic Education; Disruptive Era of Technology.

\section{INTRODUCTION}

The Disruptive technology has created very rapid lifestyle changes especially to Indonesian people [29]. The digitization in all aspects of human life led to the emergence of an era where the internet and digital media were no longer a complementary need, but a primary need. Moreover, revolutionary advances in technology and information, [23] the rapid exchange of information and knowledge, demanding the readiness of the Indonesian people to transform themselves into part of global citizenship along with their digital competencies [7].

Digital literacy as a competency that is identical to digital

Revised Manuscript Received on April 19, 2019.

Andika Limas Putra, in Civics Education Department, Faculty of Teacher Training and Education, Sebelas Maret University, Surakarta, Indonesia

Moh. Muchtarom, Civics Education Department, Sebelas Maret University of Surakarta, Central Java, Indonesia. University of Surakarta, Central Java, Indonesia.
Triana Rejekiningsih, Civics Education Department, Sebelas Maret

citizens urgently developed in society amid the current swift development of digital technology [33]. In Indonesia, the digital literacy development implies significantly high values. The number of Internet users has reached 132.7 million [34], presence actually bears an imbalance with good literacy skills of its users. This is also confirmed by data reports from the Program for International Student Assessment (PISA), it is known that Indonesia is underdeveloped in the aspect of literacy [34]. Furthermore, a study conducted by Central Connecticut State University (cited in [37]) "Indonesia was ranked 61 out of 62 countries in matters of literacy".

Being literate in the age of knowledge is a big challenge for 21st century students [24]. Students as digital natives instinctively use Information \& Computer Technology. In addition, schools as the main consumers of knowledge are responsible for creating appropriate policies aimed at developing students' digital literacy skills [30]. In addition, educators need to correlate students' digital literacy habits from their personal lives through the practice of technologybased teaching in schools [22].

Currently, many of the Civics researchers focus on three digital citizen development competencies. The first research discusses a typical useful learning to prevent students from the potential possibilities leading towards the victims and committing acts of cyber bullying, respecting others in digital media, and protecting one's personality and intellectual property in the digital world [26]. The second study then discusses how students access digital information and how they communicate with others online [9]. Then the last is how to involve students to communicate with government or public officials [8].

This study seeks to explore strategies in strengthening the digital literacy skills of santri (students of Islamic cottage) in modern Islamic boarding schools (pesantren-based schools) Indonesia through learning Citizenship Education. Developing digital literacy skills in santri is currently quite important. This is due to the santri as young citizens in the 21 st century are part of digital natives in the Internet era [22]. Having limited facilities and media for teaching [35] conventional learning habits are difficult to change [2] in fact has contributed to the potential of "digital discrepancy" [10]; [18] in the pesantren community.

Digital literacy is a sort of quite broad term. Therefore, this research will be limited to santri's strategies to develop their digital literacy skills in the era of disruption. This 
research is intended to find a way out of problems related to the use of information and communication technology, as well as addressing problems related to information literacy in digital media. Civics education as a mission bearer in establishing digital citizens is expected to be able to develop the students' knowledge and skills.

\section{REVIEW OF RELATED LITERATURE}

\section{A. Digital Literacy Skills}

Nowadays digital literacy skills have become definite competencies and urgently demanded students to be able to adjust themselves. In the 21 st century like today, students have become part of the digital indigenous population [22]. Therefore teachers as facilitators in the classroom should teach students to be able to have digital literacy skills. Digital literacy is an indispensable skill in the digital age. There are a number of views on digital literacy. The first concept of digital literacy was introduced by Gilster [15] that digital literacy is a human ability to understand and use information through various formats from various sources presented in digital media.

Ba \& Tsikalas [4] offer a broad definition of digital literacy. They describe digital literacy as "a set of habits in which children use information technology to learn, work, and have fun". Other opinions argue that digital literacy is not limited to how a person is capable of using software or operating digital devices, however, related to the complex aspects of cognitive, psychomotor, sociological and emotional skills, which enable one to evaluate various existing information in cyberspace [3].

The digital literacy skill's development concern not only the skills which one needs to have in interpreting information in digital media. Additionally, developing digital literacy concerns developing digital production skills [12]. In this case then Flew emphasizes that one capable of being care about digital information, critical of digital information, and the skills to create information through digital media..

\section{B. Santri}

The term santri sociologically viewed according to Geertz [14], a sociologist who has successfully classified Javanese society into three types; Abangan, Santri and Priyayi. Greetz further revealed that religious doctrine is the primary guideline in the lives of the santri, who in their religious practices uphold Islamic values and strict rules [13].

Another definition describes santri as individuals who study in pondok (Islamic cottage) to an ulama or kyai (traditionally associated as Islamic scholars) [31]. They are taught by the kyai and used kitab kuning 'classical Islamic literature book or literally yellow book', Islamic teachings in written texts of yellow sheets as teaching materials for pesantren curriculum [33]. Smith further revealed that a cleric plays a vital role as a prominent central figure who is highly respected and adhered to in Islamic cottage education [33]. Furthermore, according to Winarko [36], the Islamic cottage helps students develop more meaningful knowledge than those who undergo regular education in public schools.

In its development, Islamic cottage has been developed to be part of the education system and guaranteed by state law. The existence of an Islamic cottage-based education system aims not only to teach students about religion, but also encourage them to be part of the citizens who follow the world's development and progress [35]. Islamic cottages have transformed functionally from religious schools into one of the education systems in Indonesia. The educators in principle not only teach religion, but also encourage santri to take an active part in the world's advancement.

\section{Civics Education}

Regarding the rapid use of information technology and the potential to be misused, preventive measures are needed to manage, develop and control citizens' attitudes in using digital media and the internet. Flornes [12] who revealed that children and adolescents are competent as users of social media, however, they should get more attention and be educated to be wise and responsible. The important key to education lies in the teachers' mastery of the media, information literacy and being able to interact with students democratically. This is in line with the role of Civics Education in [20] Civics Education is broadly formulated including the process of preparing young people to take on their roles and responsibilities as citizens, and specifically, the role of education including schooling, teaching and learning in the process of preparing the citizen. Additionally Bishop [6] explains the purpose and mission of Civics Education as a deliberate effort to develop intelligent, democratic and religious citizens. Furthermore, according to Feriyansyah [11] both smart and good digital citizens are the ideal concept wherein any citizens living in the digital era should have. Intelligent and good digital citizens are reflected through smart and good attitudes on dealing with activities of the online community.

\section{The Era of Disruptive Technology}

Disruptive technology is basically a commercial disruption in the existing markets, where new products or services (technology) are introduced into that market [21]. Schwab [31] classifies several impacts of industry 4.0. there are five clusters namely: The economic sector is characterized by economic growth, and the nature of work; Business marked by new innovations and the latest operating models; National-Global Relations are marked by tightening international security, Societies are indicated based on inequality and new communities, Individuals who influence individual morals and ethics, as well as public and private information management. Technological disruption is closely related to innovation. Companies can create and exploit emerging technologies, capture or create markets, in addition to being able to add significant value to their profits [7].

\section{METHODS}

This research was conducted at an Islamic cottage-based Senior High School (typical Modern Pesantren) which adopts qualitative research design. The sampling uses a 
purposive sampling technique, which aims to explore the depth of goal-oriented data and related problems. Data collection techniques are obtained through interviews, observation, and document analysis. Data analysis techniques apply data reduction, data presentation, drawing conclusions and verification. Before exploring the teachings of digital literacy in santri, the researchers first analyzed the santri's demographic use of technology. Bearing the importance to know how they use the technology in their environment.

\section{RESULTS AND DISCUSSION}

\section{A. Islamic Cottage Policy \& Santri's Digital Literacy} Ability

In the first part, the researchers examined pesantren policies related to the use of ICTs and santri's demographics of digital literacy skills in modern boarding schools. Bearing in mind those policy makers in schools should begin to recognize the widespread growth of the Internet in education fields [27]. Policy bearers in schools also need to understand that in the 21 st century it is important to equip students with skills in accessing online technology, media and information [1]. Modern Islamic cottage is an educational institution transformed based on traditional Islamic cottages in Indonesia [32].

Modern Islamic cottages are divided into two types of educational institutions, namely the School-based Formal Education Institution and the education of Non-Formal Education Institution, which is the Islamic cottage itself. In its history, modern Islamic cottages use two curricula, which is the Curriculum 2013 (K13) oriented to schools and curriculum applied based on Islamic cottages which is adjusted to Islamic cottage learning models. The aforementioned problem is relevant to Wekke's study [35] which reveals that the current Islamic cottage is not only oriented towards instilling religious values, but also encourages santri to become part of the citizens who are able to adapt the world's development and progress. Based on the research findings, the development of that has taken place on Islamic cottages is a series of deep efforts to adjust to the world development in the 21 st century as today. To measure santri's ability in using ICT, this study applies three basic components, among others; Use Skill, Critical Understanding, in addition to Communicative Abilities.

Tabel 1. Santri's Individual Competence of Senior High School Walisongo, Karangmalang

\begin{tabular}{lll}
\hline $\begin{array}{l}\text { The Category } \\
\text { of Individual } \\
\text { Competence }\end{array}$ & Level & Santri's Skills \\
\hline Use Skill & Medium & $\begin{array}{l}\text { The occurring digital disparities } \\
\text { among the santri's ability to use ICTs, } \\
\text { whiich are a result of the strict rules } \\
\text { with regard to using the ICTs \& the } \\
\text { minimum ICT activities. }\end{array}$ \\
\hline Critical & Medium & $\begin{array}{l}\text { The santri are basically able to } \\
\text { understand the content, function and } \\
\text { use of digital media, only in terms of } \\
\text { the ability to find the truth of } \\
\text { information, which in this case is still } \\
\text { lacking }\end{array}$ \\
\hline
\end{tabular}

Limited to status update activities on
social media and nothing to do with
learning, criticizing social media, or
actively participating in creating
positive content in digital media

The developments that have been carried out by Islamic cottages are basically sustainable the santri's digital literacy development. Based on research findings, Islamic boarding schools apply strict rules regarding santri's use of ICT. In this case, students are only allowed to use ICT at certain times, according to their needs. However, the santri did not always comply with these regulations. There are many student violations regarding the use of ICT. A number of violations such as the use of ICT are not in accordance with the rules specified, in addition to the use of the internet in accessing negative content.

The policy of limiting the use of ICTs also had an impact on santri's digital literacy abilities. Additionally, the research findings show that not all the santri share similar basic ability to use ICT. The limited access to ICT has been a major factor in students' low mastery of ICT. This finding is in line with Jones' findings [18] who conclude that not all students living the 21 st century are currently capable of being broadly effective, and critically using digital tools.

Other santri(s) expressed different opinion. Any restriction of using the ICTs does not affect santri's skills in using ICT. Among the santri(s) are students who already shared the basic ICT skills. In santri's daily activities, the majority were found to use ICT to accommodate their tasks. The typical santri in this section is also more often seeking for information from digital media. They consider the use of ICT in their daily lives needs to be sustained in developing school leanings. Based on the aforementioned findings, it enables the researchers to conclude that there has been a "digital discrepancy" [16]; [18] in the Islamic community cottage. This is in line with the results of [19] research that the lack of access and use of ICTs hampers the pace of digital literacy development, while more access will provide opportunities to practice and develop digital literacy.

This research found that santri acquired their own skills and bear in mind about importance of ICTs, practically facilitating their lives. Basically, santri also have the ability to analyze content in digital media. This research later found that santri often access information and knowledge in digital media. However, they do not have the ability to understand the extent of the truth of information in digital media. Furthermore, santri as digital natives have in fact not yet had digital communication skills. Santri's ability to communicate on the internet is only limited in the activity of status updates on social media and has nothing to do with learning, criticizing social media, or actively participating in creating positive content in digital media.

B. Santri's Digital Literacy Development in the Age of Disruption through Civics Education Learning

Civics Education is a process of preparing young people to take on their roles and responsibilities as citizens [20]. In 
the era of disruption where the exchange of information \& knowledge can be done instantly, digital literacy is a skill that needs to be developed for santri. Based on the research findings, the development of santri's digital literacy skills through Civics education can be realized both in the process of learning and evaluation.

\section{Civics education process in Developing Santri's} Digital-based skills

Digital literacy, also known as computer literacy, is an expertise in using computer devices, the internet, and other digital devices. Digital literacy is an effort to know, search, and understand, analyze, and use digital technology. Beetham, Littlejohn and McGill mention seven elements of digital literacy [17], as illustrated in figure 1:

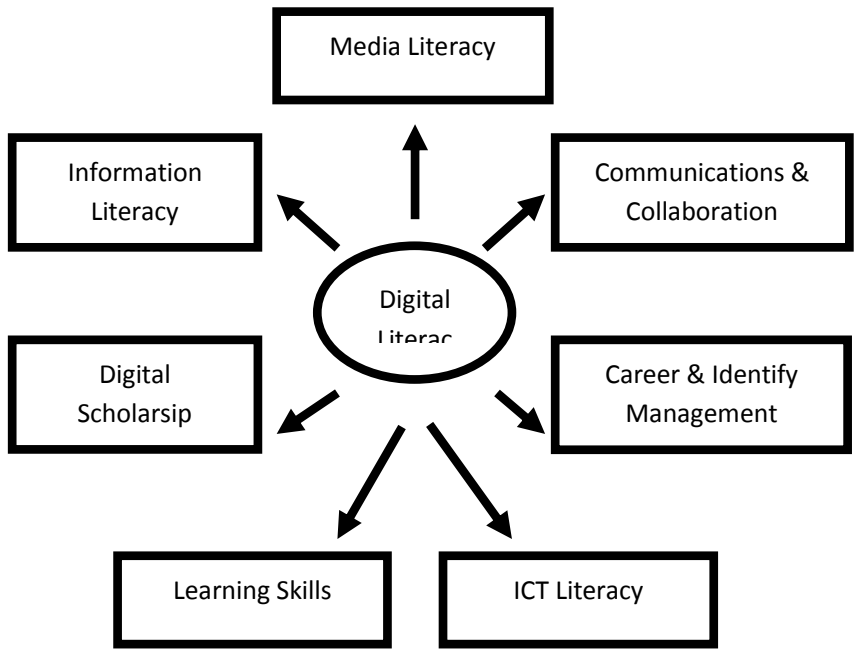

Figure 1. The Elements of Digital Literacy [17].

The digital literacy development through Citizenship Education in modern Islamic cottages has a focus on developing ICT Literacy \& Information Literacy skills for santri. This is intended to overcome the problem of digital inequality and develop information literacy skills of students. The digital literacy development as shown from the teachers of the Walisongo Senior High School in Karangmalang is realized through direct teaching and indirect teaching (indirect teaching). The Curriculum Design of 2013 allows teachers to develop contextual material and implement the ICT in the learning process. The development of digital literacy through Civics education learning can be socialized into every material in all Basic Competencies.

The development of digital literacy for santri requires his ability of teachers to integrate Civics by using the right learning strategies, in order to internalize the students' digital literacy skills of, thus, digital citizenship can be realized. This is in line with Bakkenes, et al. [5] who suggest that current digital content implementation has become an important and effective method of improving teaching and learning, which enables teachers to embrace 21 st century skills. One of the effective strategies applied for Civics education teachers in integrating students' digital literacy skills is using the Problem Based Learning method. Providing students the opportunity to access ICTs and the internet to overcome problems related to learning materials, will develop their ability to access technology, sharpen information-seeking skills, analyze information, and strengthen their identity as digital natives.
Digital literacy not only changes education standards, but also changes teaching content in schools [28]. Therefore, the development of digital literacy towards santri is realized through developing learning content through ICT and simple digital media, such as online newspapers, online learning videos, and online social media. This is as Spires \& Bartlett [34] suggest that learning model in the 21 st century require teachers' mastery of various digital resources to meet the needs of each student. In addition, NSW [25] suggest that in developing students' digital literacy, it is necessary to involve students in exploring problems in the world using digital resources.

The digital Civics concept needs to be proposed as part of the education curriculum, in addition to being one part of social studies in promoting active digital Civics. The character of digital citizenship, can incorporate the issue of digital citizenship into relevant themes, among others into the subjects of "Science, Technology, and Society", and "Civics and the Civics Practice.

\section{Civics Education Learning Evaluation in Developing} Santri's Digital Skills

Walisongo Senior High School of Karangmalang has implemented the 2013 Curriculum as the basic framework for implementing learning in schools. Evaluation in learning to develop students' digital literacy skills is highly pivotal. Some applicable strategies include appreciating the santri's skills in using technology, accessing information, communicating and creating digital creations; these strategies encourage students to develop their digital literacy skills. Flew [12] suggests that developing digital literacy equally measured with developing digital production skills. Therefore, in evaluating santri's digital skills, Civics Education teachers use a project-based learning approach. Santri will be invited to be creative by utilizing ICTs and then asked to upload in santri's each social media. Flew [12] argues that developing digital literacy means developing digital production skills. Therefore the Citizenship Education teacher in evaluating the digital skills of santri uses a project-based learning approach. Santri will be invited to be creative by utilizing ICT and then uploaded on social media of each santri.

\section{CONCLUSION}

This research reveals that santri's digital literacy development is urgently needed, bearing in mind that there is occurring digital discrepancy in the lives of santri. The development of digital literacy in santri through Civics Education is realized through direct learning and indirect learning. The development of digital literacy for santri is done by developing learning content by utilizing simple ICTs and digital media, such as online newspapers, online learning videos, and online social media. In developing santri's digital literacy, the teacher(s) should choose the right method, one of which is the Problem Based Learning method. With this method santri can develop skills in critically evaluating information contained in various media. 
Evaluation in learning is an important part of the development of digital literacy, where learning-based evaluation projects will develop students' skills and provide space for students to express themselves.

\section{ACKNOWLEDGMENT}

The researchers wish to thank the lecturers of Civics Education Study Program of Postgraduate Sebelas Maret University, Civics Education subject teachers at the Senior High School of Walisongo, Karangmalang, and students of grades X, XI, and XII who have participated in this research

\section{REFERENCES}

1. G. Ackerman, "Brief Review of Fadel, C., \& Trilling, B". 21st Century Skills: Learning for Life in Our Times. San Francisco: Jossey-Bass, 2009.

2. M. Alinejad, Nature and Domain of Islamic Education. The Social Sciences, 13, (1), 2012, pp. 93-106. doi:DOI: 10.3923/sscience.2012.90.94

3. Alkalai, \& Eshet, Digital Literacy: A Conceptual Framework for Survival Skills in the Digital Era. Jl. of Educational Multimedia and Hypermedia vol.13, (1), 2004, pp. 93-106.

4. H. Ba, W. Tally \& K.Tsikalas, "nvestigating children's emerging digital literacies". The Journal of Technology, Learning, and Assessment, vol. 1, (4), 2002, pp. 5-48.

5. I.Bakkenes, J. D.Vermunt, \& T. Wubbels, Teacher learning in the context of educational innovation: Learning activities and learning outcomes of experienced teachers. Learning and Instruction, vol.20, (6), 2010, pp. 533-548.

doi:https://doi.org/10.1016/j.learninstruc.2009.09.001

6. J. Bishop, Citizenship for the Twenty-First Century: An International Perspective on Education edited by John J. Cogan and Ray Derricott: Citizenship for the Twenty First Century. An International Perspective on Education, vol. 45, 2001.

7. A. Christensen, R.,Clayton, \& A, E. Scott, "Seing What's Next: Using the Theories of Innovation to Predict Industry Chang"e. Harvard Business Press, Boston, MA, 2013.

8. Citron, D., \& Norton, H. Intermediaries and hate speech: Fostering digital citizenship for our information age. Boston University Law Review, Vol. 91, 2011.

9. B. Dalton, C.P. Proctor, P.,Dlli, E. Mo, \& C.E. Snow. Designing for diversity: The role of reading strategies and interactive vocabulary in a digital reading environment for fifth-grade monolingual English and (1), 2011, pp. 68-100.

10. A. J. A. M. Deursen, E.Helsper, \& R. Eynon, Measuring Digital skills: From Digital Skills to Tangible Outcomes project report, 2014.

11. F. Feriyansyah, "Warga Negara Digital Sebagai Instrumen Warga Negara Global" (Penelitian Grounded Theory tentang Dampak Kemajuan TIK terhadap Praktik Kewarganegaraan). Jurnal Pendidikan Ilmu Sosial, vol. 24 (1), 2016. doi:http://dx.doi.org/10.17509/jpis.v23i1.1606

12. T. Flew, New Media: An Introduction. In Flornes, K., Promoting Civic Literacy in Teacher Education, 2017, pp. 37-50.

13. Fuad, A. B. B. Political Identity and Election in Indonesian Democracy: A Case Study in Karang Pandan Village - Malang, Indonesia. Procedia Environmental Sciences, 20, 2014, pp. 477-485. doi:https://doi.org/10.1016/j.proenv.2014.03.060 bilingual students. Journal of Literacy Research, vol. 43,

14. C.Geertz, , Religion of Java: The University of Chicago Press, 1960.

15. Gilster, P., Digital literacy. New York: John Wiley, 1977.

16. E. Helsper, \& R. Eynon, Distinct skill pathways to digital engagement, vol. 28, 2013.

17. JISC. Developping Digital Literacies: JISC, 2017

18. C. Jones, R.Ramanau, S.Cross, \& G. Healing, "Net generation or Digital Natives: Is there a distinct new generation entering university?" vol. 54, 2010.

19. J. E. Kemp, \& D. K. Dayton, Planning and Producing Instructional Media (5th Ed.). New York: Harpercollins, College Div.New Zealand, Ministry of Education, 1985.

20. D. Kerr, Citizenship Education: An International Comparison, 2005

21. M. Badawy, A. Seeing What's Next: Using the Theories of Innovation to Predict Industry Change, C.M. Christensen, S.d. Anthony, E.A. Roth Harvard Business School Press, Boston, MA, 2005, pp. 290.

22. A. Margaryan, A.Littlejohn, , \& G.Vojt, "Are digital natives a myth or reality? University students' use of digital technologies". Computers \& Education, vol56, (2), 2011, pp. 429-440. doi:https://doi.org/10.1016/j.compedu.2010.09.004

23. A. Millard, L. Baldassar \& R.Wilding, The significance of digital citizenship in the well-being of older migrants. Public Health, vol.158, 2018, pp. 144-148. doi:https://doi.org/10.1016/j.puhe.2018.03.005

24. National Research, C. Education for Life and Work: Developing Transferable Knowledge and Skills in the 21st Century. Washington, DC: The National Academies Press, 2012.

25. G.NSW, Digital Literacy Skills And Learning Report A Report On Teaching Information And Communication Technologies In Initial Teacher Education In NSW. Sidney: NSW Education Standards Authority, 2001.

26. J. Ohler, "Digital citizenship means character education for the digital age. Education Digest", essential Readings Condensed for Quick Review, vol.77, (8), 2012, pp.14 17.

27. Osterman, M. D. Digital Literacy: Definition, theoritical, framework, and competicies. Paper presented at the Procedings of the 1th College of Education \& GSN Research Conference, Miami: Florida International University, 2012.

28. M. Prensky, Digital Natives, Digital Immigrants Part 1 . Vol. 9, 2001.

29. A. Rahmah, Digital Literacy Learning System for Indonesian Citizen. Procedia Computer Science, vol.72, 2015, pp. 94-101. doi:https://doi.org/10.1016/j.procs.2015.12.109

30. K.Sandra, "Peta Gerakan Literasi Digital di Indonesia: Studi Tentang Pelaku, Ragam Kegiatan, Kelompok Sasaran dan Mitra". Informasi, vol.47, (2), 2017, pp.149166. doi:10.21831/informasi.v47i2.16079

31. Schwab, K. The fourth industrial revolution. New York: Crown Business. In. Setyaningsih, W., Nuryanti, W., Prayitno, B., \& Sarwadi, A. Urban Heritage Towards Creative-based Tourism in the Urban Settlement of Kauman - Surakarta. Procedia - Social and Behavioral Sciences, 227, 2016, pp. 642-649. doi:https://doi.org/10.1016/j.sbspro.2016.06.127

32. Shiddiq, A.,Tradisi Akademik Pesantren. vol. 10, 2015.

33. Smith, B. J., Stealing Women, Stealing Men: Co-creating Cultures of Polygamy in a Pesantren Community in Eastern Indonesia, vol. 11, 2009.

34. H.Spires, \& M. Bartlett, Digital Literacies and Learning. Designing a Path Forward. NC State University: Friday Institute White Paper Series 
International Conference on Recents Advancements in Engineering and Technology (ICRAET-18) |15th and 16th March 2019|Siddhartha Institute of Technology \& Sciences, Telangana, India.

35. I. S.Wekke, \& S. Hamid, Technology on Language Teaching and Learning: A Research on Indonesian Pesantren. Procedia - Social and Behavioral Sciences, vol.83, 2013, pp.585-589. doi:https://doi.org/10.1016/j.sbspro.2013.06.111

36. B. Winarko, Content, benefits and development of pesantren online in Indonesia. Malaysian Journal of Library and Information Science. Malaysian Journal of Library and Information Science, vol.12, 2, 2007, pp. 57-75.

37. Arif Gunawan, Indonesia second least literate of 61 nations. (The Jakarta Post, Sat, March 12, 2016. Retrieved from: https://www.thejakartapost.com/news/2016/03/12/indone sia-second-least-literate-61-nations.html

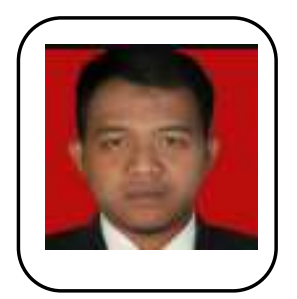

\section{AUTHORS PROFILE}

Andika Limas Putra is a student of master program in Civics Education Department, Faculty of Teacher Training and Education. Sebelas Maret University.

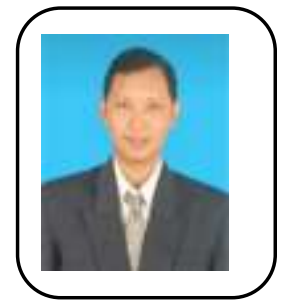

Dr. Moh. Muchtarom, S.Ag, MSI is a lecturer in Pancasila and Civics Education Department (PPKn), Faculty of Teacher Training and Education, Sebelas Maret University. He has been actively involved in various education service activities an researches in the field of political philosophy, and Civics Education.

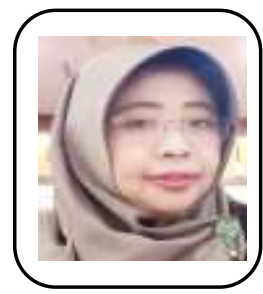

Dr. Triana Rejekiningsih, S.H., K.N., M.Pd. is a Lecturer in Civics education department of Sebelas Maret University. She has completed her doctoral education at the Indonesian Education University in 2014. Dr. Triana Rejekiningsih has actively participated in various researches at internal campus level and the Ministry of Research and Technology. Additionally, she also has actively published his writings in several internationally reputed journals 